\title{
ANALYSIS OF COMPETENCE OF APPARATUS IN PUBLIC SERVICES AT THE INVESTMENT OFFICE AND ONE-STOP INTEGRATED LICENSING SERVICE GORONTALO REGENCY
}

\author{
Dikson Junus, Suaib Napir \\ Gorontalo University, Limboto, Gorontalo District, Indonesia \\ Email: diksonjunus@gmail.com
}

\begin{abstract}
This study aims to analyze the competency of the apparatus in carrying out services to the Investment Office and the One-Stop Integrated Licensing Service (DPMPTSP) of Gorontalo Regency. This study uses a qualitative descriptive method in analyzing the competency of the field of expertise in carrying out tasks and functions of public services related to licensing. The results of the study show that the competency of the apparatus is related to knowledge and work experience. There are 11 (eleven) apparatus competencies that are based on aspects of expertise based on education, this greatly supports the implementation of DPMPTSP's duties and functions in administering government services. In carrying out the function of public service based on the competency of the apparatus, this institution has 3 (three) fields, namely the field of Investment, Licensing Services and Supervision and advocacy. The conclusion of this study, even though the competency aspects have been fulfilled, but still found public complaints related to the quality of services that have not been in line with expectations. So this research recommends increasing the competency of the apparatus through various trainings to increase the capacity of individuals in providing services to the community. Keywords: Competence, apparatus, public services.
\end{abstract}


Proceeding ICOGISS 2019

Page 466- 472 ISBN: 978-602-6 988-75-1

Web Jurnal Online: jurnal.unmuhjember.ac.id

By: Dikson Junus; Suaib Napir

Analysis Of Competence Of Apparatus In Public Services At The Investment Office And One-Stop Integrated Licensing Service Gorontalo Regency

\section{INTRODUCTION}

Law Number 25 of 2009 concerning public service article 1 states that "Public services are activities or series of activities in order to fulfill service needs in accordance with the laws and regulations for every citizen and resident for the goods, services and / or administrative services provided by public service providers ". The government as a public service provider is responsible and seeks to improve the quality of services to the community. The mandate of the act implies that public services are carried out by people who have competence. Likewise with public services carried out by government agencies, that government services can provide satisfaction to the community, therefore government officials must have competence. Competencies in question are knowledge, skills and behavior. These competencies are contained in Law Number 5 of 2014, Government Regulation Number 11 of 2017 and Regulation of the Minister of Administrative Reform and Bureaucratic Reform number 38 of 2017

Service activities carried out by government agencies in measuring the level of community satisfaction are based on Minister of Administrative Reform and Bureaucratic Reform Regulation Number 14 of 2017 concerning Guidelines for Preparing the Community Satisfaction Survey, Public Service Provider unit. The purpose of this Ministerial Regulation is to measure the level of satisfaction of the community as users of services and improve the quality of public service delivery. Initial research through literature study found: Gorontalo District Government public service performance in 2018 based on the results of the Ombudsman's assessment of Gorontalo Province showed compliance value 73.17 was in 82nd position out of 199 districts assessed, and put Gorontalo District in the yellow zone. Observations were made to assess the level of compliance with public service standards for 54 service products in Gorontalo Regency Government service units. Gorontalo District Community Satisfaction Index (IKM) based on Minister of Administrative Reform and Bureaucratic Reform Number 14 of 2017, observation report by survey team on the performance of Gorontalo District Government services in 2016 IKM value 79.89, 2017 IKM value 80.47 and in 2018 the IKM value was 85.46 with the "B" or good Community Satisfaction Index (IKM) category. The assessment given by the community determines the size of the public service performance of government organizations carried out every year.

Research Results Ratna Safitri \& Aufarul Marom note that the Community Satisfaction Survey (SKM) in the BPPT and Investment (PM) City of Salatiga in 2016 showed the results of the assessment in the good category. From the results of the Community Satisfaction Survey (SKM), it can be said that most of the community or service applicants are satisfied with the public services provided by BPPT and Investment (PM) Salatiga City, although in reality on the ground there are still complaints from some people about public services at BPPT and Investment (PM) of Salatiga City. So that efforts are still needed to improve service quality on an ongoing basis The location of this study is the Gorontalo One-Stop Service and Investment Services (DPMPTSP), a Regional Government Organization (OPD) that carries out government functions in the provision of licensing and non-licensing services. Based on the results of the Community Satisfaction Index (IKM) survey in 2017 this service obtained 77.7 IKM scores and 2018 increased so that it obtained an IKM value of 82.97 with a value of "B" or good category (ORB Section of the Regional Secretariat of Gorontalo Regency, 2018). Since it was formed based on Regent Regulation Number 53 of 2016 DPM-PTSP currently has a total of 24 employees, consisting of Masters 2 people, Bachelor 14 people, Diploma three 2 people and High School 6 people. Furthermore, there are 11 competency apparatus based on the level of education and expertise. This condition is not sufficient when compared to 
Proceeding ICOGISS 2019

Page 466- 472 ISBN: 978-602-6 988-75-1

Web Jurnal Online: jurnal.unmuhjember.ac.id

By: Dikson Junus; Suaib Napir

Analysis Of Competence Of Apparatus In Public Services At The Investment Office And

One-Stop Integrated Licensing Service Gorontalo Regency

the delegation of authority in the field of licensing and non-licensing based on Regent Regulation Number 26 of 2018. The type and number of services consists of 8 fields and 61 types of licensing services and non-licensing services consisting of 14 fields and 25 types of services This study analyzes competencies by focusing on skills and self concepts of government apparatus in carrying out service functions. The results of this study are expected to contribute, thinking for the development of public policy studies on public services. Practically it is expected to become a reference for local governments in making public service delivery policies.Miyawaki (Mohd Noor \& Dola sequence, 2009: 228) defines competence as a talent possessed by a person through natural processes and education needed by institutions to improve one's basic abilities and improve performance to a higher level according to efforts to achieve organizational goals. Another opinion about competence stated by Spencer and Spencer (1993: 9) that one's competence is the basis of the individual associated with effective and superior performance in a job. More directly Spencer, Spencer and Boyatzis (Sudarmanto, 2009 \& Sani, 2018) mention the components of competency Human resources include several things, including the focus in this paper as follows:

1. Skill and knowladge, namely knowledge or information, which a person has in a specific field. Or the ability to do or carry out certain physical tasks or certain mental tasks. Skills are capabilities that show a system or sequence of behaviors that are functionally related to achieving performance goals. Skills are also the capabilities of a person who is functionally effective or ineffective in a work situation.

2. Self concept and image, namely attitudes, values, a person's self image, or is a person's perception of himself and an evaluation of that image.

In accordance with the concept of competency of Human Resources as described above, the competency of the apparatus is related to the specification of knowledge through a tiered education process, experience in work, skills through special education, and behavior formed through the work environment. According to Kotler (Lijan Poltak Sinambela, 2011: 4-5), service is "every activity that is profitable in a group or entity, and offers satisfaction even though the results are not physically bound to a product", and public which means public, community, state . So public services can be interpreted as a profitable activity in the community that offers satisfaction and the results are not tied to a particular product. Harbani Pasolong (2010: 199), and KemenPAN number 63 of 2004 argue that public service is an activity carried out by the government as an effort to fulfill community needs. Whereas in Law Number 25 of 2009 the scope of public services includes the service of public goods and public services as well as administrative services stipulated in legislation. Based on the description of the definition of public services, it can be concluded that public service is the activity of providing services for goods or services to the public carried out by the government.

\section{RESEARCH METHODS}

This type of research is qualitative descriptive which refers to the results of the Community Satisfaction Index (IKM) survey at Gorontalo District's Investment and OneStop Services (DPMPTSP) which is the location of the study. Data collection in this study was carried out through: observations carried out directly about the state of the environment, facilities and service activities, survey reports, and interviews with officials and the community of service users. The results of the Community Satisfaction Index (IKM) survey form the basis for analyzing this research data with qualitative data analysis techniques (Miles, Huberman and Saldana, 2014: 14). 
Proceeding ICOGISS 2019

Page 466- 472 ISBN: 978-602-6 988-75-1

Web Jurnal Online: jurnal.unmuhjember.ac.id

By: Dikson Junus; Suaib Napir

Analysis Of Competence Of Apparatus In Public Services At The Investment Office And

One-Stop Integrated Licensing Service Gorontalo Regency

\section{RESEARCH RESULTS AND DISCUSSION}

\section{Apparatus Competence}

Competence is the skill or ability that a person has in relation to the work done. While the competence of government officials is more on the authority and ability of a person in carrying out tasks in a position in a government or business organization. In this paper a discussion on the competencies of Gorontalo District One-Stop Services and Investment Services (DPMPTSP) officers focuses on Skills and Knowladge competencies and the competence of Self Concept and image.

\section{Skills and Knowladge}

The competency of the apparatus in providing services is determined by the knowledge, expertise and skills possessed. The skills competency of the apparatus possessed can provide a good, fast and responsive response in responding to any complaints from the community, so that the service is maximized. To improve the skills competency of the apparatus, the Investment Services and One-Stop Integrated Services (DPMPTSP) in collaboration with the Regional Personnel Agency, Education and Training (BKD-DIKLAT), Gorontalo District has held training in order to improve the skills of officials related to public services. The training focused on strengthening individual apparatus skills related to computer operational techniques, field survey analysis, organizational management and service ethics. The ability of the apparatus to be seen in their competencies is a determining factor for the success of the service. Communities as service users have high expectations of service providers in responding to their needs. According to Kartono (2012: 13) that ability is all power, ability, strength and technical and social skills that are considered to be more than ordinary members. These types of abilities include: intelligence, analyzing, wise decision-making, organizational management and leadership, community and technical knowledge of work. This opinion indicates that in a government organization the apparatus must have the ability or strength physically and non-physically such as skills and knowledge of a job, so that they can carry out tasks and functions as public servants. In the sense of the ability of the apparatus can be seen from the results of their work or their ability to work. "The ability of the apparatus in charge has been good at providing services because they have understood what they are doing". (ST, April 2018) The ability of this apparatus to work will lead to public trust in the administration of the government, increasing community cooperation and participation in various government programs. In addition, the ability of the apparatus to work will improve the quality of service because of the response of the apparatus shown by their expertise or skills. The manifestation of quality service is the response of the community as service users, this can be used as capital in developing the knowledge of officials in the preparation of operational procedures for service procedures (SOPP). So that service providers will have a knowledge base on the form of SOPP, reasons, time, place and service processes that are in line with community expectations. In addition, what is equally important in the knowledge competence of government aaparatus is seen in the aspect of expertise through formal education. Knowledge competency of the Gorontalo District One-Stop Integrated Services and Investment Services (DPMPTSP) based on skill level can be presented in the table below: 
Proceeding ICOGISS 2019

Page 466- 472 ISBN: 978-602-6 988-75-1

Web Jurnal Online: jurnal.unmuhjember.ac.id

By: Dikson Junus; Suaib Napir

Analysis Of Competence Of Apparatus In Public Services At The Investment Office And

One-Stop Integrated Licensing Service Gorontalo Regency

Table: Competence of Apparatus Based on Expertise / Department

\begin{tabular}{clc}
\hline No & \multicolumn{1}{c}{ Bidang Keahlian Aparat } & Jumlah \\
\hline 1 & Technique & 5 People \\
\hline 2 & Mathematics & 1 Person \\
\hline 3 & Economy & 6 People \\
\hline 4 & Laws & 3 People \\
\hline 6 & Environment & 1 Person \\
\hline 7 & Health & 1 Person \\
\hline 8 & Accounting & 1 Person \\
\hline 9 & Computer & 1 Person \\
\hline 10 & Social & 3 People \\
\hline 11 & Agriculture & 1 Person \\
\hline 12 & Others & 1 Person \\
\hline & & Jumlah
\end{tabular}

Source: Dinas PMPTSP 2018

The table shows that there are 11 (eleven) areas of apparatus expertise related to the implementation of tasks, especially in the field of service. This area of expertise has become a requirement and provision in a minimum service standard (SPM). The findings of this study indicate that the competence of the government apparatus in the Gorontalo Investment Service and One-Stop Integrated Service Permit (DPMPTSP) has been good. There are 11 (eleven) knowledge competencies of the apparatus based on the field of expertise / department that can support the implementation of this service function in the administration of public service government in the Regent Regulation Number 26 of 2018. In the administration of government in Gorontalo Regency this service performs licensing and non-licensing services.

\section{Self Concept and Image}

Self concept is one of the competencies of Human Resources, which is seen in one's attitude, values, or self image. This competency can also be seen in the perceptions or judgments of others towards him. In the implementation of Gorontalo Regency Government public services, the activities of the apparatus self-concept can be seen in the aspects of politeness and friendliness of the service staff in Gorontalo District One-Stop Investment Services (DPMPTSP) indicated by the attitudes and behavior of officers in providing services to the community. The results of the research in the field indicate that courtesy and friendliness of the officers in providing services are good. Apparatus behavior is an attitude that must be shown to the community as recipients of services. As employees government or apparatus who provide services, they must show a friendly, polite attitude and listen to complaints from service recipient communities. Awareness of an officer in providing services as a form of action or attitude shown. The awareness of 
the apparatus includes the attitude of friendliness in providing services to the community is the value or self-image of an officer. The image of an apparatus is seen in the response to complaints in service, discipline, solving problems, attitudes and behavior of employees in carrying out their duties. "The hospitality of the apparatus in providing services to the community, such as providing a response to public complaints about the completeness of administrative documents". (MA, April 2018)

This shows that the image of the apparatus is shown in attitudes and behaviors in providing services to the community. "Service in managing business licenses in this service is good because some employees care about complaints, on time according to procedures. (HR April 2018) Human behavior is the result of various experiences and human interactions with the environment that are manifested in the form of knowledge, attitudes and actions. This is in line with the opinion of Notoatmojo (2010) which states; behavior is a response / reaction of an individual to a stimulus that comes from outside and from within him. Based on the understanding above and the results of observations based on the author, that friendly and polite attitude is always shown by the apparatus in providing services to the community. They are able to explain the requirements needed to arrange permits and service procedures. Communities that do not understand the requirements and licensing procedures are assisted by giving an explanation. Based on this, the apparatus in carrying out their duties are in accordance with the Operational Procedure Service Standards (SOPP) and service announcements at the Gorontalo District One-Stop Investment Services (DPMPTSP) as evidenced by the attitude of employees who are polite, friendly, responsible and professional in providing service to the community that takes care of licensing.

\section{CONCLUSION}

This study concluded that it is necessary to increase the competency of service providers in the field of computer expertise, technical, administrative management. The behavioral aspects of the apparatus in serving the community are related to friendliness in providing services. This study also suggests that it is necessary to carry out technical guidance, trainning and internships to improve skills in the field of expertise. 
Proceeding ICOGISS 2019

Page 466- 472 ISBN: 978-602-6 988-75-1

Web Jurnal Online: jurnal.unmuhjember.ac.id

By: Dikson Junus; Suaib Napir

Analysis Of Competence Of Apparatus In Public Services At The Investment Office And One-Stop Integrated Licensing Service Gorontalo Regency

\section{REFERENCE}

Kartono, Kartini. 2012. Pemimpin Dan Kepemimpinan: Apakah Kepemimpinan. Abnormal Itu? - Ed. 1, Cet, 18 -. Jakarta: Rajawali Pers.

Keputusan Menteri Pendayagunaan Aparatur Negara Nomor 63 Tahun 2004 tentang Pelayanan Publik

Lijan Poltak Sinambela, dkk. 2011. Reformasi Pelayanan Publik. Jakarta: Bumi Aksara

Mohd Noor, K. B., \& Dola K. 2009. Job Competencies for Malaysian Managers in Higher Education Institution. Asian Journal of Management and Humanity Sciences, Vol. 4, No. 4, pp. 226-240.

Ombudsman RI, 2017. Laopran Hasil Inisiatif Ombudsman. Kepatuhan Penyelenggara Terhadap Pemenuhan Komponen Standar Pelayanan Sesuai Undang-Undang Nomor 25 Tahun 2009 Tentang Palayanan Publik.

Pasolong. Harbani. 2010. Kepemimpinan Birokrasi. Bandung: CV Alfabeta

Peraturan Menteri Pendayagunaan Aparatur Negara Dan Reformasi Birokrasi Republik Indonesia Nomor 14 Tahun 2017 Tentang Pedoman Penyusunan Survei Kepuasan Masyarakat Unit Penyelenggara Pelayanan Publik

Peraturan Menteri Pendayagunaan Aparatur Sipil Negara dan Reformasi Birokrasi Republik Indonesia Nomor 38 Tahun 2017

Ratna Safitri \& Aufarul Marom. Studi Peraturan Menteri Pendayagunaan Aparatur Negara Dan Reformasi Birokrasi Nomor 1 Tahun 2015 Tentang Evaluasi Kinerja Penyelenggara Pelayanan Publik Di Badan Pelayanan Perizinan Terpadu Dan Penanaman Modal Kota Salatiga. Journal of Public Policy and Management Review Volume 6, Nomer 2, Tahun 2017

Sani, Rares, \& Ogotan. Pengembangan Kompetensi Aparatur Sipil Negara Di Dinas Pendidikan Kabupaten Intan Jaya Propinsi Papua. Jurnal Administrasi 2018 ejournal.unsrat.ac.id

Sudarmanto, 2009, Kinerja dan Pengembangan Kompetensi SDM, Teori, Dimensi Pengukuran dan Implementasi dalam Organisasi, Yogyakarta : Pustaka Pelajar.

Spencer, L.M. and Spencer, S.M. 1993. Competence at Work: Models for Superior Performance. John Wiley \& Sons. Inc.

Lumi, Rarres \& Tulusan. Pengaruh Kompetensi Pegawai Teerhadap Peningkatan Kualitas Pelayanan Publik di Kantor Pusat Universitas Sam Ratulangi Manado. Jurnal Ilmiah Society Jilid 1 Terbitan 14, Tahun 2015 